\title{
Species richness and faunistic affinities of the Gammaridea and Corophiidea (Amphipoda) from shallow waters of southern Tierra del Fuego, Argentina: preliminary results*
}

\author{
IGNACIO LUIS CHIESA ${ }^{1}$, GLORIA MARÍA ALONSO² and DIEGO GABRIEL ZELAYA ${ }^{3}$ \\ ${ }^{1}$ Departamento de Biodiversidad y Biología Experimental, Facultad de Ciencias Exactas y Naturales, Universidad de \\ Buenos Aires, Ciudad Universitaria, C1428EHA Buenos Aires, Argentina. E-mail: ichiesa@bg.fcen.uba.ar \\ ${ }^{2}$ Museo Argentino de Ciencias Naturales "Bernardino Rivadavia", Av A. Gallardo 470, C1405DJR \\ Buenos Aires, Argentina. \\ ${ }^{3}$ Museo de La Plata, Div. Zoología Invertebrados, Paseo del Bosque s/n, 1900, La Plata, Buenos Aires, Argentina.
}

\begin{abstract}
SUMMARY: Species richness and faunistic affinities of gammaridean and corophiidean amphipods from southern Tierra del Fuego were studied. The material was collected with dredges and grabs at 7 locations ( 15 sampling stations) in a range of 5 to $35 \mathrm{~m}$ depth. A total of 61 species belonging to 20 families and 43 genera were identified. The genera Cephalophoxoides, Ceradocopsis and Photis are reported for the first time from the Magellan region and 3 species belonging to Atylus, Ischyrocerus and Photis appear to be new to science. Most of the species collected belong to Phoxocephalidae, whereas most individuals were contained in the Stenothoidae and Lysianassidae s.l. The analysis of the faunistic affinities showed that 16 species (39\%) are endemic to the Magellan region, 9 species (22\%) extend to the south, 5 species (12.2\%) to the north and 5 other species $(12.2 \%)$ to both the north and south. In addition, 6 species extend beyond the Magellan region as far as Oceania.
\end{abstract}

Keywords: Magellan region, Beagle Channel, Amphipoda, diversity, distribution.

RESUMEN: - RiQUEZA DE ESPECIES Y AFINIDADES FAUNíSTICAS DE GAMMARIDEA Y COROPHIIDEA (AMPHIPODA) DE AGUAS SOMERAS DEL SUR DE TIERRA DEL FuEGO, ARGENTINA: RESUlTAdOS PRELIMINARES. - Se estudió la diversidad y las afinidades faunísticas de los anfípodos gammarideos y corophiideos del sur de Tierra del Fuego. El material fue recolectado utilizando rastras y dragas en 7 sitios (15 estaciones de muestreo) a un rango de profundidad entre 5 y 35 metros. Un total de 61 especies pertenecientes a 20 familias y 43 géneros fueron identificadas. Los géneros Cephalophoxoides, Ceradocopsis y Photis son citados por primera vez para la región magallánica, y 3 especies de los géneros Atylus, Ischyrocerus y Photis parecen ser nuevas para la ciencia. Phoxocephalidae resultó la familia con mayor número de especies, mientras que Stenothoidae y Lysianassidae s.l. fueron las más abundantes. El análisis de las afinidades faunísticas reveló que 16 especies (39\%) son endémicas de la región magallánica, 9 especies $(22 \%)$ se extienden hacia el sur, 5 especies $(12,2 \%)$ hacia el norte y otras $5(12,2 \%)$ están presentes en el norte y en el sur. Además, 6 especies se extienden más allá de la región magallánica alcanzando Oceanía.

Palabras clave: región magallánica, Canal Beagle, Amphipoda, diversidad, distribución.

\section{INTRODUCTION}

The gammaridean and corophiidean amphipods (Crustacea, Peracarida, Amphipoda) represent a

*Received April 2, 2004. Accepted April 21, 2005. widely diversified group of invertebrates in benthic communities from the Magellan region. Based on extensive collections along the Chilean coasts and data from the literature, a total of 206 species were listed by De Broyer and Rauschert (1999). In contrast, the amphipod fauna from the Argentine sector 


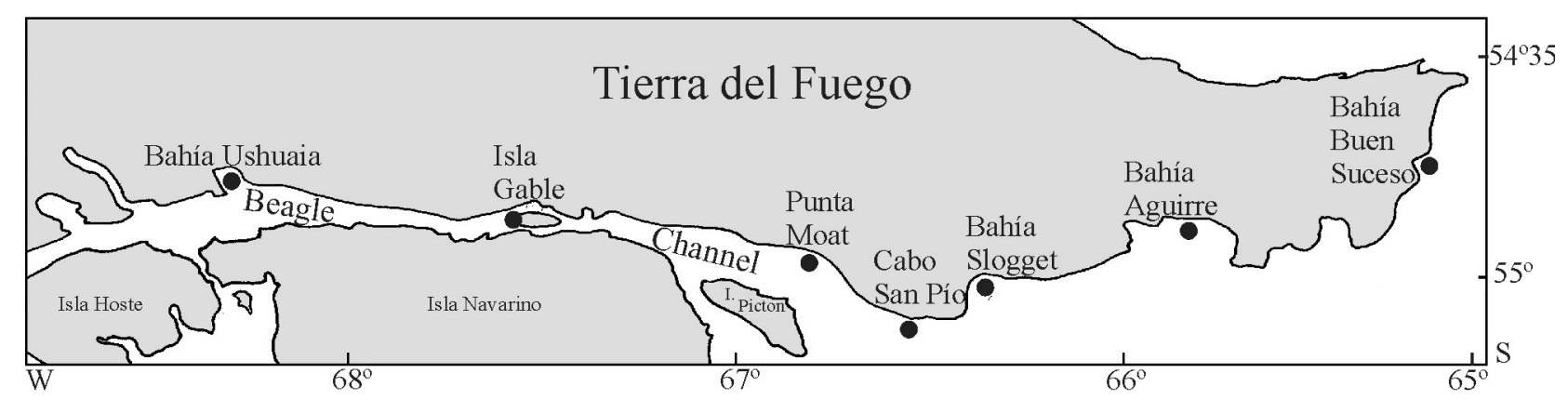

FIG. 1. - Sampling locations in southern Tierra del Fuego.

of the Magellan region still remains scarcely studied. Unfortunately, the main contributions for the area by Schellenberg (1931) and Barnard (1932) have overlooked important details in their descriptions of species, and most of them need revision and redescription. Recently, several species have been described from the provinces of Santa Cruz and Chubut, but the knowledge on the group is sparse in Tierra del Fuego, where only a few studies carried out by Alonso (1987a,b, 1989) and Alonso de Pina (1993a, 1997a) provided the description of 2 new species and the addition of 3 new records of distribution. The low number of species presently known from the Argentine waters of the Magellan region is probably due to the lack of extensive field surveys conducted in this area.

The present work provides the first results on the species richness and faunistic affinities of the Gammaridea and Corophiidea collected in southern Tierra del Fuego. The sampling area is not only of great biogeographic interest due to its proximity to the Subantarctic islands and the Antarctic, but also represents a transitional region between the Atlantic and Pacific oceans.

\section{MATERIAL AND METHODS}

Seven locations (comprising a total of 15 sampling stations) were established along the Beagle Channel and its eastern mouth, at the southern coast of Tierra del Fuego, Argentina (Fig. 1, Table 1). All stations were selected within a relatively homogeneous bathymetric range ( 5 to $35 \mathrm{~m}$ ) in order to avoid depth-related effects. A total of 6 samples were obtained with a dredge of $45 \times 50 \mathrm{~cm}$ mouth and 2 $\mathrm{mm}$ mesh. The dredge was pulled for 7 minutes at Isla Gable, Punta Moat, Cabo San Pío, Bahía Slogget, Bahía Aguirre and Bahía Buen Suceso (Fig. 1). In addition, the contents of grab samples (Snapper and Van Veen, $0.07 \mathrm{~m}^{2}$ ) taken at 9 sampling stations in Bahía Ushuaia were received from colleagues and considered altogether for this study (Table 2).

The material was fixed in $10 \%$ formalin. Amphipods were sorted from the sediment under a stereoscopic microscope, preserved in $70 \%$ ethanol, and identified to the lowest taxonomic level. The taxonomic classification of the amphipods follows Barnard and Karaman (1991) and Myers and Lowry (2003).

TABLE 1. - Sampling locations

\begin{tabular}{|c|c|c|c|c|c|}
\hline Locations & Date & Latitude & Longitude & Depth (m) & Sampler \\
\hline \multicolumn{6}{|l|}{ Bahía Ushuaia } \\
\hline Península Ushuaia & $27 / 10 / 96$ & $54^{\circ} 51^{\prime} \mathrm{S}$ & $68^{\circ} 19^{\prime} \mathrm{W}$ & $5-10$ & Van Veen Grab \\
\hline Bahía Golondrina & $12 / 2 / 97$ & $54^{\circ} 50^{\prime} \mathrm{S}$ & $68^{\circ} 20^{\prime} \mathrm{W}$ & 5 & Snapper Grab \\
\hline Bahía Golondrina & $12 / 2 / 97$ & $54^{\circ} 50^{\prime} \mathrm{S}$ & $68^{\circ} 19^{\prime} \mathrm{W}$ & 5 & Snapper Grab \\
\hline Bahía Golondrina & $12 / 2 / 97$ & $54^{\circ} 50^{\prime} \mathrm{S}$ & $68^{\circ} 14^{\prime} \mathrm{W}$ & 5 & Snapper Grab \\
\hline Bahía Golondrina & $10 / 2 / 97$ & $54^{\circ} 49^{\prime} \mathrm{S}$ & $68^{\circ} 14^{\prime} \mathrm{W}$ & 12 & Snapper Grab \\
\hline Bahía Golondrina & $10 / 2 / 97$ & $54^{\circ} 50^{\prime} \mathrm{S}$ & $68^{\circ} 16^{\prime} \mathrm{W}$ & 30 & Snapper Grab \\
\hline Bahía Golondrina & $10 / 2 / 97$ & $54^{\circ} 49^{\prime} \mathrm{S}$ & $68^{\circ} 17^{\prime} \mathrm{W}$ & 30 & Snapper Grab \\
\hline Isla Lucas & $10 / 12 / 97$ & $54^{\circ} 50^{\prime} \mathrm{S}$ & $68^{\circ} 19^{\prime} \mathrm{W}$ & 17 & Snapper Grab \\
\hline Pozo Angel & $12 / 2 / 97$ & $54^{\circ} 52^{\prime} \mathrm{S}$ & $68^{\circ} 15^{\prime} \mathrm{W}$ & 23 & Snapper Grab \\
\hline Isla Gable & $11 / 5 / 01$ & $54^{\circ} 54^{\prime} \mathrm{S}$ & $67^{\circ} 21^{\prime} \mathrm{W}$ & $15-20$ & Dredge \\
\hline Punta Moat & 2/9/01 & $55^{\circ} 02^{\prime} \mathrm{S}$ & $66^{\circ} 42^{\prime} \mathrm{W}$ & $15-25$ & Dredge \\
\hline Cabo San Pío & 29/9/02 & $55^{\circ} 03^{\prime} \mathrm{S}$ & $66^{\circ} 37^{\prime} \mathrm{W}$ & $30-35$ & Dredge \\
\hline Bahía Slogget & $2 / 9 / 01$ & $55^{\circ} 00^{\prime} \mathrm{S}$ & $66^{\circ} 21^{\prime} \mathrm{W}$ & $15-27$ & Dredge \\
\hline Bahía Aguirre & $2 / 2 / 00$ & $54^{\circ} 54^{\prime} \mathrm{S}$ & $65^{\circ} 57^{\prime} \mathrm{W}$ & $30-35$ & Dredge \\
\hline Bahía Buen Suceso & $8 / 2 / 01$ & $54^{\circ} 47^{\prime} \mathrm{S}$ & $65^{\circ} 14^{\prime} \mathrm{W}$ & 12 & Dredge \\
\hline
\end{tabular}


The number of species and specimens were determined for each locality.

For the analysis of the faunistic affinities, the following areas were considered:

a) Magellan region: comprising the Malvinas (Falkland) Islands, the Argentine coast south of Península Valdés and the Chilean coast south of Isla Chiloé; the southern limit is Cape Horn (Boschi, 2000).

b) "North of the Magellan region": embracing the coasts north of Península Valdés (Atlantic Ocean) and Isla Chiloé (Pacific Ocean), including the Brazilian, Uruguayan, Peruvian and northern Argentinean and Chilean waters.

c) "South of the Magellan region": includes the Scotia Arc islands (South Georgia, South Sandwich Islands, South Orkney Islands and South Shetland Islands), the Subantarctic islands (Kerguelen, Crozet, Campbell, Macquarie, Auckland, Prince Edward and Marion Islands) and the Antarctic.

Data for these areas were obtained from Schellenberg (1931), K. H. Barnard (1932), Lowry and Bullock (1976), González (1991), De Broyer and Jazdzewski (1993), Wakabara and Serejo (1998) and De Broyer and Rauschert (1999). In the analysis of faunistic affinities, the new species and those reported as "sp." or "cf." were not considered.

\section{RESULTS}

\section{Species richness of amphipods}

A total of 3,928 specimens were examined during this study and 41 species were identified (Table 2); another 20 species (reported as "sp." or "cf." in Table 2) were recognised as different taxa. In total, 61 species belonging to 43 genera and 20 families were reported (Table 2 ). The present study provides the first records of the genera Cephalophoxoides, Ceradocopsis and Photis from the Magellan region and of 18 species from the Beagle Channel. Moreover, 3 species belonging to Atylus, Ischyrocerus and Photis appear to be new to science (Table 2).

Among the twenty families recognised, Phoxocephalidae had the highest number of species (7). Ten families had 3 to 6 species, and nine families only 1-2 species (Table 2). A high number of genera also had a low number of species: 34 genera were only represented by 1 species each; three genera (Atyloella, Atylus and Iphimedia) by 2 species each; and four genera (Liljeborgia, Probolisca,
Pseudiphimediella and Seba) by 3 species each. Gammaropsis and Gondogeneia had 4 and 5 species each respectively (Table 2).

Stenothoidae and Photidae were the families that accounted for the highest number of specimens ( 887 and 797 respectively), followed by Lysianassidae s.l. (575) and Eusiridae s.l. (458). The remaining 16 families were consistently less abundant (Table 2). Among the Stenothoidae, Probolisca nasutigenes was the most abundant species (545 specimens), followed by $P$. ovata (189 specimens) and $P$. elliptica (153 specimens). Among the Photidae, Gammaropsis deseadensis was the most abundant species (485 specimens). All other species were represented by fewer than 300 specimens, including 41 species that were represented by fewer than 35 specimens each (Table 2).

Tryphosites chevreuxi was the most frequent species, being present at all locations, whereas Phoxorgia sinuata was found at 6 out of 7 locations (Table 2). The highest number of species (29) was found in the sample from Bahía Slogget, followed by those from Punta Moat (28 species) and Bahía Ushuaia (26 species), whereas the highest abundance $(1,211$ specimens) was found at Cabo San Pío (Table 2).

\section{Faunistic affinities}

For the 41 amphipod taxa identified at species level in this study, 16 species (39\%) are known only from the Magellan region (Table 3) and the ranges of 24 species extend beyond this region: 9 (22\%) to the south, $5(12.2 \%)$ to the north, and $5(12.2 \%)$ to both the north and the south (Fig. 2). Another 6 species extend beyond the Magellan region, reaching Oceania: 2 of them (Bircenna fulva and Seba typica) are known only from this allopatric distribution; Jassa alonsoae is also present in South Georgia and the Subantarctic islands; Eusirus antarcticus is also present in the Scotia Arc islands, Subantarctic islands and Antarctica; Probolisca ovata is also distributed north of the Magellan region; and Eusiroides monoculoides is found in the Magellan region, Subantarctic islands, South Africa, and Oceania (Lowry and Bullock, 1976; De Broyer and Jazdzewski, 1993; De Broyer and Rauschert, 1999).

For the 14 species extending south of the Magellan region, 5 (Fuegiphoxus fuegiensis, Liljeborgia octodentata, Pariphimedia normani, Phoxorgia sinuata and Seba subantarctica) reach only the Scotia Arc islands, 6 (Amphilochus marionis, Gammarop- 
TABLE 2. - List of species of Gammaridea and Corophiidea collected in southern Tierra del Fuego. Total number of species and specimens for each location; $\bullet$ : new records for the Magellan region; X: new records for the Beagle Channel. Locations = BU: Bahía Ushuaia, IG: Isla Gable, PM: Punta Moat, CP: Cabo San Pío, BS: Bahía Slogget, BA: Bahía Aguirre, BB: Bahía Buen Suceso. Distribution = M: Magellan region, S: south of the Magellan region, N: north of the Magellan region, O: other localities.

Species

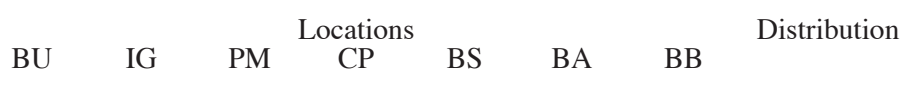

Ampeliscidae

Ampelisca sp.

Amphilochidae

Amphilochus marionis Stebbing, 1888

Aoridae

X Lembos argentinensis Alonso de Pina, 1992

Corophiidae

Corophium sp.

X Haplocheira barbimana robusta K.H. Barnard, 1932

Dexaminidae

Atylus (Atylus) sp. n.

Atylus (Atylus) cf. villosus Bate, 1862

X Paradexamine nana Stebbing, 1914

Eophliantidae

X Bircenna fulva Chilton, 1884

Eusiridae s. $\mathbf{l}$.

X Atyloella dentata K.H. Barnard, 1932 Atyloella magellanica (Stebbing, 1888)

$\mathbf{X}$ Eusiroides monoculoides (Haswell, 1879) Eusirus antarcticus Thomson, 1880 Paramoera cf. fissicauda (Dana, 1852) Gammarellidae

Austroregia regis (Stebbing, 1914)

Gondogeneia cf. antarctica (Chevreux, 1906)

Gondogeneia gracilicauda (Schellenberg, 1931)

Gondogeneia cf. macrodon (Schellenberg, 1931)

X Gondogeneia patagonica Alonso, 1986

Gondogeneia cf. thurstoni Alonso, 1989

Gammaridae s.l.

- Ceradocopsis sp.

Maera sp.

Iphimediidae

X Iphimedia magellanica Watling and Holman, 1980 Iphimedia multidentata (Schellenberg, 1931) Pariphimedia normani (Cunningham, 1871) Pseudiphimediella glabra (Schellenberg, 1931)

X Pseudiphimediella nodosa (Dana, 1852) Pseudiphimediella sp.

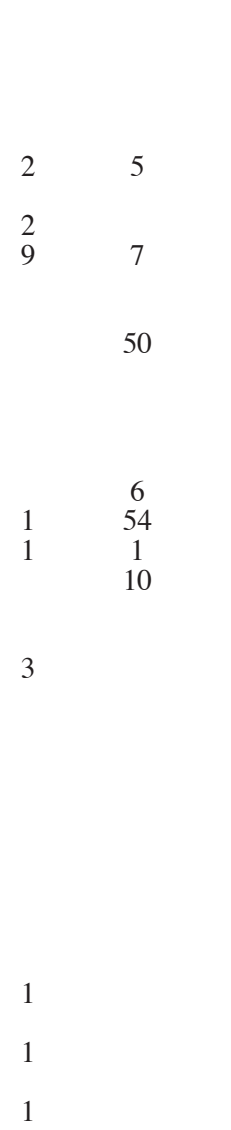

Ischyroceridae

Ischyrocerus $\mathrm{sp} . \mathrm{n}$.

Jassa alonsoae Conlan, 1990

Notopoma sp.

Ventojassa georgiana (Schellenberg, 1931)

Liljeborgiidae

Liljeborgia cf. macrodon Schellenberg, 1931

Liljeborgia octodentata Schellenberg, 1931

Liljeborgia sp.

Lysianassidae s. $\mathbf{l}$.

X Erikus dahli Lowry and Stoddart, 1987 Tryphosella schellenbergi (Schellenberg, 1931) Tryphosites chevreuxi Stebbing, 1914

X Uristes serratus Schellenberg, 1931 Stomacontion $\mathrm{sp}$.

Oedicerotidae

Oediceroides cf macrodactylus Schellenberg, 1931

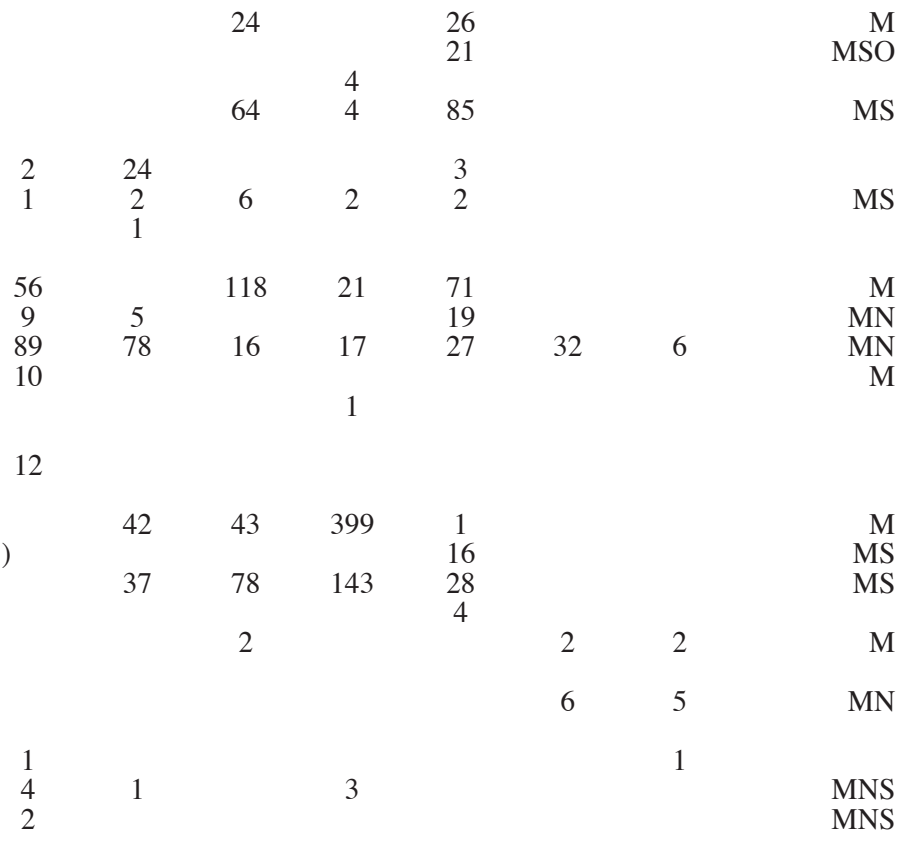

170 I.L. CHIESA et al. 
TABLE 2 (Cont.). - List of species of Gammaridea and Corophiidea collected in southern Tierra del Fuego. Total number of species and specimens for each location; $\bullet$ new records for the Magellan Region. X: New records for the Beagle Channel. Locations = BU: Bahía Ushuaia, IG: Isla Gable, PM: Punta Moat, CP: Cabo San Pío, BS: Bahía Slogget, BA: Bahía Aguirre, BB: Bahía Buen Suceso. Distribution = M: Magellan Region, S: south of the Magellan Region, N: north of the Magellan Region, O: other localities.

\begin{tabular}{|c|c|c|c|c|c|c|c|c|}
\hline \multirow[t]{2}{*}{ Species } & \multicolumn{7}{|c|}{ Locations } & \multirow{2}{*}{ Distribution } \\
\hline & $\mathrm{BU}$ & IG & PM & $\mathrm{CP}$ & BS & $\mathrm{BA}$ & $\mathrm{BB}$ & \\
\hline Microphoxиs cornutus (Schellenberg, 1931) & 57 & & & & & & & MN \\
\hline X Parafoxiphalus longicarpus Alonso de Pina, 2001 & 45 & & & & & 32 & & $\mathrm{M}$ \\
\hline $\mathbf{X}$ Phoxorgia sinuata (K. H. Barnard, 1932) & 20 & 19 & 9 & 20 & 14 & & 2 & MNS \\
\hline Proharpinia stephenseni (Schellenberg, 1931) & 6 & & & & & & 1 & M \\
\hline Sebidae & & & & & & & & \\
\hline Seba saundersii Stebbing, 1875 & 16 & & & & & & & MS \\
\hline Seba subantarctica Schellenberg, 1931 & 1 & & & & & & & MS \\
\hline X Seba typica (Chilton, 1884) & & & & & 1 & & & MO \\
\hline Stenothoidae & & & & & & & & \\
\hline Probolisca elliptica (Schellenberg, 1931) & & 97 & 3 & 50 & 3 & & & MS \\
\hline X Probolisca nasutigenes (Stebbing, 1888) & & 342 & 13 & 177 & 13 & & & MNS \\
\hline Probolisca ovata (Stebbing, 1888) & 2 & & 4 & 50 & 133 & & & MNSO \\
\hline Urothoidae & & & & & & & & \\
\hline X Urothoe falcata Schellenberg, 1931 & & & 3 & 1 & & 27 & 21 & $\mathrm{MN}$ \\
\hline Total number of species & 26 & 18 & 28 & 25 & 29 & 9 & 10 & \\
\hline Total number of specimens & 354 & 781 & 631 & 1211 & 679 & 182 & 90 & \\
\hline
\end{tabular}

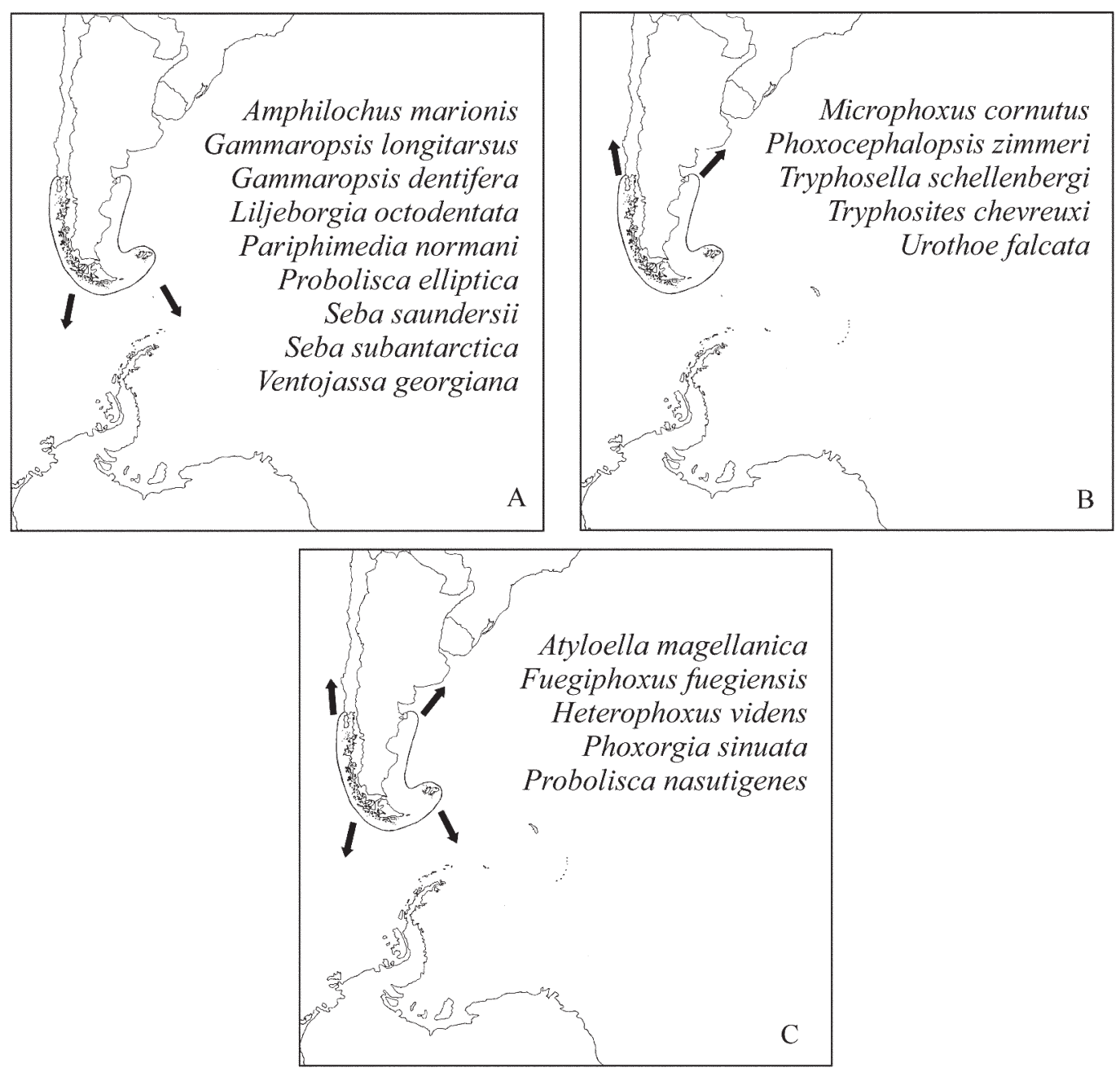

FIG. 2. - Distribution of species from southern Tierra del Fuego. A: Magellan species distributed towards the south; B: Magellan species distributed towards the north; C: Magellan species distributed towards both the north and the south. 
TABLE 3. - Distribution of the species collected during the present study in southern Tierra del Fuego known hitherto only from the Magellan region. PO, Pacific Ocean; SM, Straits of Magellan; AO, Atlantic Ocean.

\begin{tabular}{lccc}
\hline Species & PO & SM & AO \\
\hline $\begin{array}{l}\text { Atyloella dentata } \\
\text { Austroregia regis }\end{array}$ & & & $\mathrm{X}$ \\
$\begin{array}{l}\text { Erikus dahli } \\
\text { Gammaropsis (Gammaropsis) deseadensis }\end{array}$ & $\mathrm{X}$ & $\mathrm{X}$ & $\mathrm{X}$ \\
$\begin{array}{l}\text { Gondogeneia gracilicauda } \\
\text { Gondogeneia patagonica }\end{array}$ & & $\mathrm{X}$ \\
Haplocheira barbimana robusta & & & $\mathrm{X}$ \\
Iphimedia magellanica & & & $\mathrm{X}$ \\
Iphimedia multidentata & $\mathrm{X}$ & $\mathrm{X}$ & $\mathrm{X}$ \\
Lembos argentinensis & & $\mathrm{X}$ & $\mathrm{X}$ \\
Paradexamine nana & & & $\mathrm{X}$ \\
Parafoxiphalus longicarpus & & $\mathrm{X}$ & $\mathrm{X}$ \\
Proharpinia stephenseni & $\mathrm{X}$ & $\mathrm{X}$ & $\mathrm{X}$ \\
Pseudiphimediella glabra & & $\mathrm{X}$ & $\mathrm{X}$ \\
Pseudiphimediella nodosa & & $\mathrm{X}$ & $\mathrm{X}$ \\
Uristes serratus & & & \\
\hline
\end{tabular}

sis dentifera, $G$. longitarsus, Probolisca elliptica, $P$. nasutigenes and Seba saundersii) extend to the Subantarctic islands and 3 (Atyloella magellanica, Heterophoxus videns and Ventojassa georgiana) reach the Antarctic continent.

Table 3 shows the geographic distribution of the 16 species collected during this study that were known exclusively from the Magellan region: 8 of them are also present in the Atlantic Ocean, 1 in the Straits of Magellan and 1 in the Pacific Ocean, 3 in the Straits of Magellan and the Atlantic Ocean, and 3 in the Straits of Magellan and also in the Atlantic and Pacific oceans. None of the species was endemic to the Beagle Channel.

\section{DISCUSSION}

The present study provides new information on the species richness of the shallow-water amphipod fauna from southern Tierra del Fuego, giving the first records of 3 genera from the Magellan region and reporting 18 species for the first time from the Beagle Channel. In addition, 3 probable new species are reported.

De Broyer and Rauschert (1999) listed 206 gammaridean and corophiidean species from the Magellan region. The present contribution adds to this list: two species described by Alonso de Pina (1993b and 1997c) and 2 records reported by Alonso de Pina (1997b) that were omitted by De Broyer and Rauschert; 4 new species described from the area by Alonso de Pina (2000, 2001, 2003); and the records from this study ( 2 species belonging to the genera Ceradocopsis and Cephalophoxoides and 3 apparently undescribed species). These additions increase the species number of the Magellan region to 219. Sixty-one out of these species $(27.9 \%)$ were found in southern Tierra del Fuego during this study. The relatively low number of species in this area as compared to the entire Magellan region could be a consequence of the few samples examined and the narrow bathymetric range considered herein. In fact, although Stenothoidae is the most speciose family in the Magellan region (more than 36 species were listed by De Broyer and Rauschert, 1999), only 3 species were collected during this study. This low number is probably due to the deep-water habitat of most stenothoids and to the relatively large mesh size used. The higher number ( 7 species) of phoxocephalids found (the most speciose family in this study) seems to be related to their sand-burrowing habit and a different sampling method: most of the phoxocephalid species and specimens were collected from Bahía Ushuaia, where a grab was used as the sampling device.

Gammarellidae, Lysianassidae s.l. and Eusiridae s.l., which have high species diversity in the Magellan region, were also well represented in southern Tierra del Fuego. Six out of 8 iphimediid species reported for the whole Magellan region were collected in southern Tierra del Fuego during this study. This fact is probably related to the low sampling depth since iphimediids are predominantly shallowwaters inhabitants.

Although dredge samples are not strictly quantitative, they provide a large amount of material with a relatively low effort (Arntz et al., 1999). For this reason, they are useful for taxonomic studies, but the number of specimens caught should be considered only a crude estimate of abundance. The total number of species collected in Bahía Aguirre (9) and Bahía Buen Suceso (10) was lower than at the remaining locations, probably due to the faster speed of the sampling vessel that resulted in an inappropriate performance of the dredge. Moreover, the high number of species and the low number of specimens found at Bahía Ushuaia seems to be related to the sampling method used: grabs frequently capture a lower number of specimens than dredges, but they can penetrate more deeply into the substrate, thus obtaining more infaunal species.

The occurrence of Magellanic species present also at localities north of the Magellan region is probably related to the Malvinas, Patagonic and 
Humboldt currents, three water masses which run northward reaching Brazil and Buenos Aires (Bastida et al., 1992; Piola and Rivas, 1997), and Peru and Ecuador respectively (Brattström and Johanssen, 1983). Similarly, the presence of Magellanic species in the Scotia Arc islands, Subantarctic islands and Oceania is favoured by the West Wind Drift/Antarctic Circumpolar Current, regarded as a means of dispersion of other groups of invertebrates (Fell, 1962; Dell, 1972; Helmuth et al., 1994; Castilla and Guiñez, 2000).

This study provides preliminary results on the species richness of the shallow amphipod fauna living in southern Tierra del Fuego. Additional samples are needed to confirm the taxonomic status of the 20 amphipods reported as sp. or cf. in this study and to improve the knowledge on the diversity and faunistic affinities of this region. Further investigations are also required in the southwest Atlantic Ocean, in order to determine the current distribution of the amphipods present in the Magellan region.

\section{ACKNOWLEDGEMENTS}

We thank the staff of the Base Naval Ushuaia for their logistic support, particularly Mr. M. Matesa and Mr. J. Amato, Commanders of A.R.A. Alférez Sobral, for the assistance offered to one of us (DZ) in the collection of the samples; Dr. Gustavo A. Lovrich for his kind help with the survey arrangements; Dr. Daniel Roccatagliata for supplying us with the sample taken at the Península Ushuaia, and Dr. Juan J. López Gappa for his valuable comments on the manuscript. We also thank the Departamento de Biodiversidad (FCEyN, UBA) for laboratory facilities. This research was partially supported by the Consejo Nacional de Investigaciones Científicas y Técnicas (CONICET, Argentina) and the FCEyN, UBA through the scholarship given to the first author (IC). The present contribution was partially supported by the Agencia Nacional de Promoción Científica y Tecnológica - ANPCyT (PICT No. 11.180).

\section{REFERENCES}

Alonso, G.M. - 1987a. Estudios sistemáticos de tres Lysianassidae (Amphipoda, Gammaridea) de la Argentina. Physis (Buenos Aires), Secc. A, 45(108): 1-10.

Alonso, G.M. - 1987b. Sobre la presencia de Parawaldeckia kidderi (Smith) (Amphipoda, Lysianassidae) en el Mar Argentino. Physis (Buenos Aires), Secc. A, 45(108): 17-20.
Alonso, G.M. - 1989. Gondogeneia thurstoni new species (Amphipoda, Eusiridae) from the south-west Atlantic, Argentina. Crustaceana, 56(1): 1-7.

Alonso de Pina, G. - 1993a. Pachychelium barnardi, new species, from Argentina, and the occurrence of other lysianassids on the Argentine continental shelf (Amphipoda: Lysianassidae). $J$. Crust. Biol., 13(2): 377-382.

Alonso de Pina, G.M. - 1993b. Linca pinita, a new phoxocephalid genus and species (Crustacea: Amphipoda) from the Argentine continental shelf. P. Biol. Soc. Wash., 106(3): 497-507.

Alonso de Pina, G.M. - 1997a. New Exoediceropsis Schellenberg (Crustacea: Amphipoda: Exoedicerotidae) from the Argentine continental shelf and re-description of $E$. chiltoni Schellenberg. J. Nat. Hist., 31(1): 85-97.

Alonso de Pina, G.M. - 1997b. Records of intertidal amphipods from the southwest Atlantic, with the description of a new species of Elasmopus. J. Crust. Biol., 17(4): 745-757.

Alonso de Pina, G.M. - 1997c. Paramonoculopsis acuta, a new genus and species of Oedicerotidae (Amphipoda) from the south-west Atlantic, Argentina. Crustaceana, 70(2): 145-154.

Alonso de Pina, G.M. - 2000. Eophoxocephalopsis colombus, a new species (Crustacea: Amphipoda: Phoxocephalopsidae) from the southwest Atlantic. P. Biol. Soc. Wash., 113(3): 710-720.

Alonso de Pina, G.M. - 2001. Two new phoxocephalids (Crustacea: Amphipoda: Phoxocephalidae) from the south-west Atlantic. $J$. Nat. Hist., 35(4): 515-537.

Alonso de Pina, G.M. - 2003. A new species of Phoxocephalidae and some other records of sand-burrowing Amphipoda (Crustacea) from Argentina. J. Nat. Hist., 37(9): 1029-1057.

Arntz, W.E., M. Gorny, R. Soto, M.A. Lardies, M. Retamal and I.S. Wehrtmann. - 1999. Species composition and distribution of decapod crustaceans in the waters off Patagonia and Tierra del Fuego, South America. Sci. Mar., 63(Suppl. 1): 303-314.

Barnard, K.H. - 1932. Amphipoda. Discovery Rep., 5: 1-326.

Barnard, J.L. and G.S. Karaman. - 1991. The families and genera of marine gammaridean Amphipoda (except marine gammaroids). Rec. Aust. Mus., Suppl. 13 (Part 1): 1-417 (Part 2): 419-866.

Bastida, R., A. Roux and D.E. Martínez. - 1992. Benthic communities of the Argentine continental shelf. Oceanol. Acta, 15(6): 687-698.

Brattström, H. and A. Johanssen. - 1983. Ecological and regional zoogeography of the marine benthic fauna of Chile. Sarsia, 68(4): 289-339.

Boschi, E.E. - 2000. Species of decapod crustaceans and their distribution in the American marine zoogeographic provinces. Rev. Invest. Des. Pesq., 13: 7-136.

Castilla, J.C. and R. Guiñez. - 2000. Disjointed geographical distribution of intertidal and nearshore benthic invertebrates in the Southern Hemisphere. Rev. Chil. Hist. Nat., 73(4): 585-603.

De Broyer, C. and K. Jazdzewski. - 1993. Contribution to the marine biodiversity inventory. A checklist of the Amphipoda (Crustacea) of the Southern Ocean. Doc. Trav. Inst. Roy. Sci. Nat. Belg., 73: 1-154.

De Broyer, C. and M. Rauschert. - 1999. Faunal diversity of the benthic amphipods (Crustacea) of the Magellan region as compared to the Antarctic (preliminary results). Sci. Mar., 63(Suppl. 1): 281-293.

Dell, R.K. - 1972. Antarctic benthos. Adv. Mar. Biol., 10: 1-216.

Fell, H.B. - 1962. West wind drift dispersal of echinoderms in the southern hemisphere. Nature, 193: 759-761.

González, E. - 1991. Actual state of gammaridean Amphipoda taxonomy and catalogue of species from Chile. Hydrobiologia, 223: 47-68.

Helmuth, B., R.R. Veit and R. Holberto. - 1994. Long-distance dispersal of a Subantarctic brooding bivalve (Gaimardia trapesina) by kelp-rafting. Mar. Biol., 120: 421-426.

Lowry, J.K. and S. Bullock. - 1976. Catalogue of the marine gammaridean Amphipoda of the Southern Ocean. B.R. Soc. NZ., 16: 1-187.

Myers, A.A. and J.K. Lowry. - 2003. A phylogeny and a new classification of the Corophiidea Leach, 1814 (Amphipoda). J. Crust. Biol., 23: 443-485.

Piola, A.R. and A.L. Rivas. - 1997. Corrientes en la plataforma continental. In: E.E. Boschi (ed.), El mar Argentino y sus recursos pesqueros. Tomo 1. Antecedentes históricos de las exploraciones en el mar y las características ambientales, pp. 119132. Inst. Nac. Invest. Des. Pesq. (INIDEP), Mar del Plata. 
Schellenberg, A. - 1931. Gammariden und Caprelliden des Magellangebietes, Südgeorgiens und der Westantarktis. Further Zool. Res. Swed. Antarctic Exped. 1901-1903, 2(6): 1-290.

Wakabara, Y. and C.S. Serejo. - 1998. Malacostraca - Peracarida.
Amphipoda. Gammaridea and Caprellidea. In: P.S. Young (ed.), Catalogue of Crustacea of Brazil, pp. 561-594. Río de Janeiro, Museu Nacional. 